\title{
Knowledge Level of Pregnant Women in Cipacing Village on Nutrition and Benefits of Colostrums
}

\author{
Haviz Reddy ${ }^{1}$, Siti Nur Fatimah ${ }^{2}$, Zulvayanti ${ }^{3}$ \\ ${ }^{1}$ Faculty of Medicine, Universitas Padjadjaran, ${ }^{2}$ Department of Medical Nutrition, Faculty of \\ Medicine, Universitas Padjadjaran, ${ }^{3}$ Department of Obstetry and Gynecology, Faculty of Medicine, \\ Universitas Padjadjaran/Dr. Hasan Sadikin General Hospital, Bandung
}

\begin{abstract}
Background: Colostrums are the only natural food that is healthy for newborn infants since colostrums contain proper nutrition needed for infants' growth. This study aimed to reveal the knowledge level of pregnant women on nutrition and benefits of colostrums.

Methods: This study used descriptive cross-sectional method on 73 pregnant women in Cipacing village, Jatinangor district, Sumedang Regency, West Java, from October 18 to November 14, 2012. A questionnaire was used.

Results: The results showed that the characteristics of these pregnant women were as follows: 20-35 years old (53.4\%), most were middle school graduates $(42.5 \%)$, most were unemployed $(72.6 \%)$, and some claimed to have never given birth before (37,0\%). Mostly, the knowledge level of these pregnant women was in the category of "favorable" (84.9\%). The knowledge level with the highest percentage (100\%) came from pregnant women aged above 35 years old, college graduates, employed as private employees, civil servants, or self-employed, as well as having three biological children or more.

Conclusions: Sustained health promotion and counseling programs are needed to maintain alreadyfavorable knowledge level; thus pregnant women's knowledge on nutrition and benefits of colostrums can be applied and can also encourage these women themselves to provide colostrums for their newborn infants.
\end{abstract}

Keywords: Benefits of colostrums, Jatinangor, nutrition, women's knowledge level

\section{Introduction}

Colostrums are secretions similar to milk, produced in female human breasts during the final period of pregnancy until one to three days after laboring or before transitional breast milk is produced. ${ }^{1}$ Colostrums have a yellow hue in color and are more condensed than breast milk since colostrums contain beta-caroten. ${ }^{2}$

Several benefits of colostrums for newborn infants are as follows: as a laxative-like substance to clean the colon of the infant, as well as cleaning the meconium to allow the digestive tract to digest food; as a substance rich in immunoglobulin, particularly Immunoglobulin A (IgA), which provides protections against bacterial infections, viruses, fungal infections, and allergens. Colostrums can protect the infant's body against infections and diseases for almost six months since colostrums are rich in leukocytes and bifidus factors that help stimulate the growth of good bacteria Lactobacillus. Colostrums consist of proteins and enzymes with much more quantity than breast milk, thus colostrums can also help stimulate good growth and metabolism of body cells. Aside from proteins, colostrums also contain fat-soluble vitamins as well as minerals, particularly vitamin A and carotene that help maintain eye health. Colostrums are low in fat and lactose than breast milk, thus providing balanced nutrients for newborn infants during their first days after birth. ${ }^{1,3}$

Low levels of colostrums feeding to infants become one of many factors that trigger disturbances in the infant's overall growth. Infants that do not consume enough colostrums and breast milk in a proper way can also increase the risks of suffering from nutrition disorder, and they become more prone to diseases such as indigestion, upper respiratory tract infection (URTI), allergies, as

Correspondence: Haviz Reddy, Faculty of Medicine, Universitas Padjadjaran, Jalan Raya Bandung-Sumedang Km.21, Jatinangor, Sumedang, Indonesia, Phone: +6282125416781 Email: havizreddy@gmail.com 
well as affecting their viability and longevity. ${ }^{4}$

Low levels of colostrums-feeding to infants have also been included as one of many factors that affect infant mortality rate (IMR), which becomes the indicator of the degree of public health. According to the data in 2004, infant mortality rate in several regions in southern regions of West Java shows fairly high infant mortality rates, occurring in Garut where it reaches 53.79 per 1000 live births, followed by Tasikmalaya Regency (48.75) as well as Cianjur (50.87). In 2008, the IMR is still above 40 per 1,000 live births in West Java province, where there are 10 regions with the highest number of infant mortality. ${ }^{5-7}$

Cipacing village is one of villages located in Jatinangor District, Sumedang Regency, West Java. According to health records retrieved from Jatinangor Local Clinic (Puskesmas Jatinangor), in 2011 there are several cases recorded, namely upper respiratory tract infection (URTI) on infants, nutrition disorder on infants, as well as high rates of pregnant women among other villages in Jatinangor District. Diseases such as URTI and nutrition disorder can be resulted from many factors, which one of them is low levels of colostrumsfeeding to infants and toddlers, and this factor is also influenced dominantly by mothers' knowledge level. ${ }^{8}$

Based on the explanation above, depictions of the knowledge level of pregnant women in Cipacing village, Jatinangor District, Sumedang Regency, nutrition and benefits of colostrums were required since there were no adequate amount of data of knowledge level of pregnant women on nutrition and benefits of colostrums generally in West Java province and particularly in Sumedang Regency. Pregnant women were chosen as the main subject of the study since they are required to utilize their knowledge on nutrition and benefits of colostrums after giving birth to their newborn infants. The result, in the form of a depiction of knowledge on nutrition and benefits of colostrums, is expected to become a part of consideration made by health care providers in providing counseling activities, in order to improve or maintain the efforts in informing pregnant women to affect their decision in feeding colostrums to their infants after giving birth, particularly among pregnant women in Cipacing village, Jatinangor District, Sumedang Regency.

\section{Methods}

This study used descriptive survey research method using cross-sectional approach to reveal the depiction of knowledge level of pregnant women in Cipacing village, Jatinangor district, Sumedang Regency, on nutrition and benefits of colostrums in such an objective way. This study was conducted on 73 respondents during the period from October 18 to November 14, 2012.

All pregnant women in Cipacing village, Jatinangor district, Sumedang Regency based on records of pregnant women were retrieved from midwives and neighborhood health centres or 'posyandu'in Cipacing village, Jatinangor district in September 2012, which was available and accepted the terms of this study. Cipacing village itself is divided into 18 neighborhood councils or 'RW', with two midwives dividing these RW into two working areas. Besides, Cipacing village itself has 18 health centres or 'posyandu' run by health workers in each RW. Based on questionnaires, the knowledge level of pregnant women on nutrition and benefits of colostrums was divided into three categories: favorable, mediocre, and less favorable. Analysis was conducted in the form of frequency distribution or percentage of each variable. This univariate analysis aims to reveal frequency distribution and proportional amount of each characteristic examined in this research.

Numeric data were described by explaining the lowest score, the highest score, the average score, and the standard deviation. Furthermore, category data were examined in the form of frequency distribution table or using formulas.

\section{Result}

Table 1 showed that pregnant women with

Table 1 Knowledge Level of Pregnant Women on Nutrition and Benefits of Colostrums

\begin{tabular}{|lcc|}
\hline \multicolumn{1}{|c}{ Knowledge Level } & Frequency (people) & Percentage (\%) \\
\hline Favorable & 62 & $84.93 \%$ \\
Mediocre & 4 & $5.48 \%$ \\
Less favorable & 7 & $9.59 \%$ \\
\hline
\end{tabular}


Table 2 Knowledge Level of Pregnant Women on Nutrition and Benefits of Colostrums, Based on Age

\begin{tabular}{ccccccc}
\hline & \multicolumn{5}{c}{ Knowledge Level } \\
\cline { 2 - 6 } Age (years) & \multicolumn{2}{c}{ Favorable } & \multicolumn{2}{c}{ Mediocre } & \multicolumn{2}{c}{ Less Favorable } \\
\cline { 2 - 7 } & $\mathbf{F}^{*}$ & $\mathbf{\%}^{*}$ & $\mathbf{F}^{*}$ & $\mathbf{\%}^{*}$ & $\mathbf{F}^{*}$ & $\mathbf{\%}^{*}$ \\
\hline$<20$ & 4 & $66.70 \%$ & 0 & $0.00 \%$ & 2 & $33.30 \%$ \\
$20-35$ & 32 & $82.10 \%$ & 3 & $7.70 \%$ & 4 & $10.30 \%$ \\
$>35$ & 26 & $92.90 \%$ & 1 & $3.60 \%$ & 1 & $3.60 \%$ \\
\hline
\end{tabular}

favorable knowledge level were in the highest frequency, with a fairly huge difference with other categories, mediocre and less favorable.

Table 2 showed that all 73 pregnant women involved in the study, the favorable knowledge level on nutrition and benefits of colostrums with the highest percentage, come from pregnant women under the category of "above 35 years old". The category of "below 20 years old" showed the highest frequency of mediocre knowledge level. Based on these results, it can be inferred that there are certain tendencies: the younger these pregnant women, the lower the knowledge level on nutrition and benefits of colostrums. It can also be inferred that the older these pregnant women, the higher the knowledge level.

Table 3 showed that 73 pregnant women in this study, the favorable knowledge level on nutrition and benefits of colostrums with the highest percentage $(100 \%)$ come from pregnant women with education levels of diploma-III and bachelor degree. On the other hand, on the education levels of elementary school, junior high school, and senior high school, the knowledge levels are not entirely favorable.

Table 4 showed that 73 pregnant women

Table 3 Knowledge Level of Pregnant Women on Nutrition and Benefits of Colostrums, Based on Education Level

\begin{tabular}{ccccccc}
\hline & \multicolumn{6}{c}{ Knowledge Level } \\
\cline { 2 - 7 } Education Level & \multicolumn{2}{c}{ Favorable } & \multicolumn{2}{c}{ Mediocre } & \multicolumn{2}{c}{ Less Favorable } \\
\cline { 2 - 7 } & $\mathbf{F}^{*}$ & $\mathbf{\%}^{*}$ & $\mathbf{F}^{*}$ & $\mathbf{\%}^{*}$ & $\mathbf{F}^{*}$ & $\mathbf{\%}^{*}$ \\
\hline Elementary & 6 & $60.00 \%$ & 1 & $10.00 \%$ & 3 & $30.00 \%$ \\
Junior High & 24 & $88.89 \%$ & 0 & $0.00 \%$ & 3 & $11.11 \%$ \\
Senior High & 27 & $87.10 \%$ & 3 & $9.68 \%$ & 1 & $3.23 \%$ \\
Diploma-III & 1 & $100.00 \%$ & 0 & $0.00 \%$ & 0 & $0.00 \%$ \\
Bachelor degree & 4 & $100.00 \%$ & 0 & $0.00 \%$ & 0 & $0.00 \%$ \\
\hline
\end{tabular}

Table 4 Knowledge Level of Pregnant Women on Nutrition and Benefits of Colostrums, Based on Occupation

\begin{tabular}{ccccccc}
\hline \multirow{2}{*}{ Occupation } & \multicolumn{7}{c}{ Knowledge Level } \\
\cline { 2 - 7 } & \multicolumn{2}{c}{ Favorable } & \multicolumn{2}{c}{ Mediocre } & \multicolumn{2}{c}{ Less Favorable } \\
\cline { 2 - 7 } & $\mathbf{F}^{*}$ & $\mathbf{\%}^{*}$ & $\mathbf{F}^{*}$ & $\mathbf{\%}^{*}$ & $\mathbf{F}^{*}$ & $\mathbf{\%}^{*}$ \\
\hline Housewife & 44 & $83.02 \%$ & 4 & $7.54 \%$ & 5 & $9.43 \%$ \\
Private Employee & 11 & $100.00 \%$ & 0 & $0.00 \%$ & 0 & $0.00 \%$ \\
Labor & 3 & $60.00 \%$ & 0 & $0.00 \%$ & 2 & $40.00 \%$ \\
Civil Servants & 2 & $100.00 \%$ & 0 & $0.00 \%$ & 0 & $0.00 \%$ \\
Self-employed & 2 & $100.00 \%$ & 0 & $0.00 \%$ & 0 & $0.00 \%$ \\
\hline
\end{tabular}


Table 5 Knowledge Level of Pregnant Women on Nutrition and Benefits of Colostrums, Based on the Number of Biological Children

\begin{tabular}{|c|c|c|c|c|c|c|}
\hline \multirow{3}{*}{$\begin{array}{l}\text { Number of } \\
\text { Biological } \\
\text { Children }\end{array}$} & \multicolumn{6}{|c|}{ Knowledge Level } \\
\hline & \multicolumn{2}{|c|}{ Favorable } & \multicolumn{2}{|c|}{ Mediocre } & \multicolumn{2}{|c|}{ Less Favorable } \\
\hline & $\mathrm{F}^{*}$ & $\% *$ & $\mathrm{~F}^{*}$ & $\% *$ & $\mathbf{F}^{*}$ & $\% *$ \\
\hline 0 & 19 & $70.40 \%$ & 3 & $11.10 \%$ & 5 & $18.50 \%$ \\
\hline 1 & 17 & $89.50 \%$ & 1 & $5.30 \%$ & 1 & $5.30 \%$ \\
\hline 2 & 17 & $94.40 \%$ & 0 & $0.00 \%$ & 1 & $5.60 \%$ \\
\hline 3 & 8 & $100.00 \%$ & 0 & $0.00 \%$ & 0 & $0.00 \%$ \\
\hline 4 & 1 & $100.00 \%$ & 0 & $0.00 \%$ & 0 & $0.00 \%$ \\
\hline
\end{tabular}

in this study can be inferred that knowledge level of pregnant women with occupation as Civil Servants, Private Employees, and SelfEmployed were in the category of "favorable". Pregnant women working as labors and housewives did not entirely have favorable knowledge level.

Table 5 showed that in this study, only pregnant women having three biological children or more had favorable knowledge level on nutrition and benefits of colostrums, with $100 \%$ percent. Pregnant women who already had two children or less, had lesser percentage of favorable knowledge level. The data showed that in this research, there was a tendency that a pregnant mother having more biological children would have better knowledge level on nutrition and benefits of colostrums.

\section{Discussions}

Based on this study, most of pregnant women have favorable knowledge level. This is influenced by primary health care providers such as 'puskesmas' that gives counseling and socialization on nutrition and benefits of colostrums for newborn infants as well as how health care workers such as midwives in every health care center play a huge role in promoting and informing pregnant women to improve their knowledge on the importance of colostrums due to its nutrition and benefits for newborn infants.

Most of these pregnant women are in their optimum reproduction age. ${ }^{9}$ Pregnancy during optimum reproduction allows the mother to give birth normally or per vaginam, thus having greater chances to breastfeed her newborn infant. The experience of breastfeeding newborn baby and the support from health workers who help the labor process and intervene the mother to immediately provide colostrums to her baby can also affect her knowledge level on nutrition and benefits of colostrums. ${ }^{10}$

Pregnant women with higher risks of labor due to young age (below 20 years old) can suffer from diseases or pathological conditions such as pre-eclampsia, eclampsia, or premature birth. Pregnant women below 20 years old also tend to ignore pre-natal treatments, thus preventing them from getting informed on nutrition and benefits of colostrums from health workers. ${ }^{11}$ This can lead to abnormal conditions both during pregnancy and labor, where there are greater chances of the mother to labor with pathological conditions, or non per vaginam. ${ }^{9,11}$ This will also result in situations preventing the mother to immediately breastfeed her newborn baby with colostrums due to loss unconsciousness after laboring, thus affecting her knowledges on nutrition and benefits of colostrums. ${ }^{9,10}$

Based on this study, there is a tendency where the lower the education level, the lower the knowledge level on nutrition and benefits of colostrums. This is in accordance with the theory by Notoatmodjo ${ }^{10}$, stating that one's education level also determine their capability of getting information. However, it does not necessarily mean that those with education level of elementary school do not have proper knowledge level.

With several other factors affecting knowledge level, it can also be concluded that education levels should not necessarily become the absolute benchmark to determine one's knowledge level. 10Nevertheless, education should always remain as the main, important point since studies conducted in many countries in Asia and Africa regions have shown that there are positive effects between mother's knowledge level and the health 
condition of the mother and her children. ${ }^{12}$

Based on this study, pregnant women working as labors and housewives do not entirely have favorable knowledge level. Employed mothers indirectly allow themselves to get more interactions outside their home, thus they do not have a lot of time spent at home than housewives do. However, interactions with many people in their own communities also allow good circulations of information, thus there is a tendency that employed mothers can have broader knowledge and insights than those who are unemployed.

Most of 73 pregnant women in this study are pregnant women with nullipara. The least number found in this research is pregnant women with three children. Any other factors that can contribute to the results of this study are the use of contraception or birth control, or the family planning program that has been widely spread among people in Cipacing village.

Mothers with a first-time pregnancy or nullipara do not have experience of providing colostrums to the baby himself. Women who have never given birth tend not to come into contact with health professionals who help the delivery process, so that it affects the low level of knowledge about the nutritional value and benefits of colostrums. ${ }^{10}$ Women who have given birth once or more will generally produce colostrum faster with higher numbers progressively compared to women who have never given birth. ${ }^{12}$ This may affect the level of experience and knowledge level of the mother, because the experience gained can later be converted into one knowledge. ${ }^{10}$

Sustained and continuous health promotion is required to maintain already-favorable knowledge level and improve less favorable knowledge level among pregnant women in Cipacing village, Jatinangor district. Such health promotion by health workers is not the mere factor that affects the knowledge level of women, especially mothers, on nutrition and benefits of colostrums. Notoatmodjo argued that apart from proper information, other factors that matter are as follows: age, education, experience, social life, and culture. ${ }^{10}$

Health workers can minimize roles of other such factors, thus health promotion or counseling programs can always be maintained and improved frequently in the form of counseling programs for particular age, experience, education level, and culture of pregnant women themselves. Further studies are required to determine the factors that affect infant mortality in district and sub- district Sumedang Jatinangor and factors that influence the incidence of upper respiratory tract infections and nutritional disorders in infants in the village Cipacing, District Jatinangor.

\section{References}

1. Whitney E, Rolfes SR. Understanding nutrition. 11th ed. Belmont: Thompson Wadsworth; 2008. p.550-1.

2. American Pregnancy Association. Breastfeeding: overview. 2012; [update 2012; downloaded in 27 April 2012]; Available at: http:// americanpregnancy.org/first-yearof-life / breastfeeding-overview /

3. American Pregnancy Association. What's in breast milk?. 2012; [updated 2011; downloaded in 27 April 2012]; Available at: http://americanpregnancy.org/ first-year-of-life/whats-in-breastmilk/

4. Pusat Komunikasi Publik Sekretariat Jenderal Kementerian Kesehatan RI. Banyak sekali manfaat ASI bagi bayi dan ibu. Jakarta: Pusat Komunikasi Publik, Sekretariat Jenderal Kementerian KesehatanRI;2011; [downloadedin28April 2012];Available at: http://www.depkes. go.id/article/view/1450/banyak-sekalimanfaat-asi-bagi-bayi-dan-ibu--.html.

5. Dinas Kesehatan Provinsi Jawa Barat. KematianbayidiIndonesiabanyakterjadidi masa neonatal. Bandung: Dinas Kesehatan Provinsi Jawa barat 2012; [update 2012, downloaded in 26April 2012]; Available at: http://www.diskes.jabarprov. go.id/index.php/post/read/2012/26/ Ke matian-Bayi-di-IndonesiaBanyak-Terjadi-di-Masa-Neonatal/g

6. Heryawan A. Agenda Pemerintah Provinsi Jawa Barat Triwulan III Juni-September 2008. Bandung: Pemerintah Provinsi Jawa Barat; 2008. [donwloaded in 26April 2012]; Available at: http://jabarprov.org/docs/ perencanaan/20080702_085315.pdf

7. Pemerintah Provinsi Jawa Barat. Kesehatan. Bandung: Pemerintah Provinsi Jawa Barat; 2004; [downloaded in 26April 2012]; Available at: http://www. google.com/url?sa $=t \& r c t=j \& q=\&$ esrc $=s$ \& source $=$ web \&cd $=1 \&$ ved $=0$ CDEQFjAA \&url=http\%3A\%2F\%2Fwww.jabarprov. go.id $\% 2$ Fr o ot $\% 2$ F i p m $\% 2$ F B A BV. ke seh atan 04 .d oc \& e i $=$ N J w A U a K l H ovxr Qf U 6 o G I D w \& u s g = A F Qj C N Ef Q 93 Q F D 039 R C x R K S ZtpPBCOqw\&bvm=bv.41524429, d.bmk 
8. Hapsari D. Telaah berbagai faktor yang berhubungan dengan pemberian ASI pertama (Kolostrum). 2001; [downloaded in 26 April 2012]; Available at: file http:// cgi.fisipol.ugm.ac.id/index.php/id/ component/attachments/download/64.

9. Saifuddin $\mathrm{AB}$, Rachimhadhi T, Wiknjosastro GH. Ilmu Kebidanan Sarwono Prawirohardjo.4thed.Jakarta:BinaPustaka Sarwono Prawirohardjo; 2009. p. 375-6.

10. Soekidjo N. Prinsip-prinsip dasar ilmu kesehatan masyarakat. 5th ed. Jakarta: Rineka Cipta; 2004. p. 127-30.

11. Beers MH, Porter RS, Jones TV, Kaplan
JL, Berkwits M. High-risk pregnancy. 2010; [downloaded in 19 November 2012]; Available at: http://www.health. am/pregnancy/high-risk-pregnancy/\#7

12. Solihah I, Lindawati, Miradwiyana B, Taufiqqurahman, Suryati B, Suryani, et al. Faktor - faktor yang berhubungan dengan pemberian ASI dalam satu jam pertama setelah lahir di Kabupaten Garut, Provinsi Jawa Barat: analisis survei data dasar pengembangan model pelayanan kesehatan neonatal esential di Kabupaten Garut, Jawa Barat, Tahun 2007. Media Litbang Kesehatan. 2010;20(2):79-90 